\title{
Hierarchical cobalt phenylphosphonate nanothorn flowers for enhanced electrocatalytic water oxidation at neutral $\mathrm{pH}$
}

\author{
Mei-Rong Liu a,b,†, Yang-Peng Lin a,b,†, Kai Wang c, Shumei Chen a,*, Fei Wang b, Tianhua Zhou b,\# \\ a College of Chemistry, Fuzhou University, Fuzhou 350108, Fujian, China \\ b State Key Laboratory of Structural Chemistry, Fujian Institute of Research on the Structure of Matter, Chinese Academy of Sciences, Fuzhou 350002, \\ Fujian, China \\ c College of Chemistry and Materials Science, Sichuan Normal University, Chengdu 610068, Sichuan, China
}

\section{A R T I C L E I N F O}

\section{Article history:}

Received 25 February 2020

Accepted 29 March 2020

Published 5 October 2020

\section{Keywords:}

Phosphate

Morphology

Electrocatalysis

Neutral pH

Oxygen evolution reaction

Phosphonates

\begin{abstract}
A B S T R A C T
Cobalt-based phosphate/phosphonates are a class of promising water oxidation catalysts at neutral $\mathrm{pH}$. Herein, we reported a facile hydrothermal synthesis of various nanostructured cobalt phenylphosphonates. It is found that the number of hydroxyl group of structure-directing reagent is crucial for the construction of 3D hierarchical structures including hierarchical nanosheet flower-like assemblies and nanothorn microsphere. These samples were characterized by scanning electron microscopy, transmission electron microscopy, X-ray diffraction, infrared, and X-ray photoelectron spectroscopy techniques. They can act as highly efficient electrocatalysts for the oxygen evolution reaction at neutral $\mathrm{pH}$. Among these, hierarchical cobalt phenylphosphonate nanothorn flowers present excellent performance, affording a current density of $1 \mathrm{~mA} \mathrm{~cm}{ }^{-2}$ required a small overpotential of $393 \mathrm{mV}$. This work offers a new clue to develop high-performance metal phosphonate/phosphate catalysts toward electrochemical water oxidation.
\end{abstract}

(c) 2020, Dalian Institute of Chemical Physics, Chinese Academy of Sciences. Published by Elsevier B.V. All rights reserved.

\section{Introduction}

Solar-driven water splitting is a promising approach to generate hydrogen fuels as a renewable clean energy, which alleviate the global energy crisis and environmental problem caused by fossil fuels [1-9]. However, the inherent sluggish kinetics of oxygen evolution reaction (OER) limits the efficiency of water splitting because the OER reaction proceed via a complex multistep proton-coupled electron transfer process [10]. Thus, OER is recognized as the bottleneck of water splitting. To improve the efficiency of water splitting, durable and highly efficient OER catalysts are required. Currently, the outstanding OER catalysts are mainly noble metals such as $\mathrm{IrO}_{2}$ and $\mathrm{RuO}_{2}$ $[11,12]$, but their high cost and scarcity severely limit the large scale application. To this end, considerable efforts have been made on the development of highly efficient and low-cost OER catalysts from earth-abundant transition metal.

Currently, various transition-metal-based OER catalysts have been developed as alternatives to noble metals catalysts, such as $3 d$ transition metal oxides [13-18], oxyhydroxides, carbides [19,20], phosphates [21], oxide perovskites [22,23], layered double hydroxides [24-28], metal-organic frameworks [29-37], and molecular complexes [38-41]. Among these reported catalysts, cobalt based OER catalysts, especially, cobalt

\footnotetext{
* Corresponding author. Tel: +86-591-63179450; E-mail: csm@fzu.edu.cn

\# Corresponding author. E-mail: thzhou@fjirsm.ac.cn

+ Contributed equally to this work.

This work was supported by the National Natural Science Foundation of China $(51772291,21871050)$.

DOI: S1872-2067(19)63513-8 | http://www.sciencedirect.com/science/journal/18722067 | Chin. J. Catal., Vol. 41, No. 10, October 2020
} 
phosphates, have attracted increasing interest owning to their unique electronic structure [42-44]. Among these, cobalt phosphate (Co-Pi) from in-situ electrodeposition has been considered as one of the most efficient OER catalysts to date $[44,45]$. The excellent OER performance of Co-Pi could be attributed to the Co oxo/hydroxo cluster consisting of cord-sharing [46] or edge-sharing $\mathrm{CoO}_{6}$ octahedra identified by the extended X-ray absorption fine structure (EXAFS) spectrum [47]. The unidentified structure motifs could derive from its ill-defined amorphous structure. The amorphous materials make it more difficult to reveal the correlation between the local coordination geometry and the OER mechanism. By contrast, well-defined transition metal phosphates/phosphonates, featuring robust stability and displays versatile structures due to the presence of the flexible coordination of the phosphate groups, could provide a platform to understand the interplay between structure and properties [10]. Especially, recent studies demonstrated that the phosphate groups not only induce surface reorganization and stabilize the formed highly distorted polyhedral geometry of the metal center [48-51], but also tune the coordination geometry of metal center [48], and consequently affect the reaction pathway and regulate the OER catalytic activity [52]. Recently, we found that the OER activity also depended on the coordination geometry as well as the bond length of Co-O and Co-Co [10,53,54]. The compound with edge-sharing cobalt cluster exhibits higher activity than that with core-sharing ones [10]. However, only a few of cobalt-based phosphonates were developed as OER catalysts [10,53-55]. Furthermore, most of reports mainly focus on the effect of the coordination geometry on OER activity. In contrast, only a class of shape-dependence in OER catalysis for metal phosphate was explored [56]. The study of the shape-dependence of the OER catalysis driven by metal-organic phosphonates still remains unexplored and has highly demanded.

Based on the above consideration, we herein report a facile hydrothermal synthesis of hierarchical nanostructured cobalt phenylphosphonate frameworks (CoP-X) via a structure-directing strategy (Scheme 1). The growth mechanism of different morphologies was tentatively proposed. These as-prepared cobalt phosphonates can be directly used as effi-

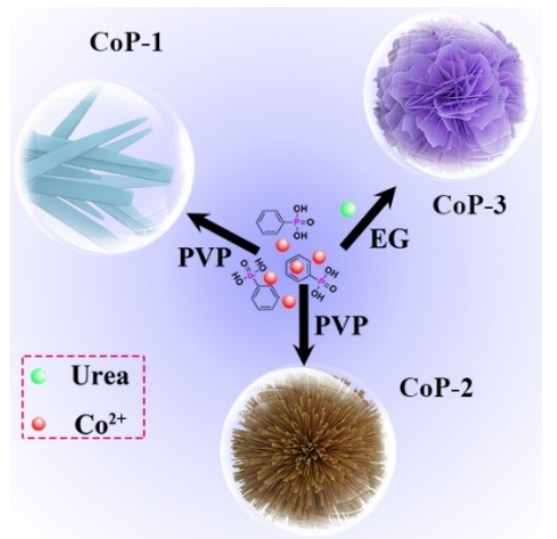

Scheme 1. Schematic Illustration of the synthesis of nanostructured cobalt phenylphosphonates CoP-X. cient OER catalysts under neutral conditions. Interestingly, the hierarchical flower (CoP-2) delivers a small overpotential of $393 \mathrm{mV}$ at $1 \mathrm{~mA} \mathrm{~cm}^{-2}$ and a Tafel slope of $81 \mathrm{mV} \mathrm{dec}^{-1}$.

\section{Experimental}

\subsection{Materials}

Cobalt nitrate hexahydrate $\left(\mathrm{Co}\left(\mathrm{NO}_{3}\right)_{2} 6 \mathrm{H}_{2} \mathrm{O}, 98 \%\right)$, cobalt acetate tetrahydrate $\left(\mathrm{Co}(\mathrm{OAc})_{2} 4 \mathrm{H}_{2} \mathrm{O}, 98 \%\right)$, ammonium carbonate $\left(\left(\mathrm{NH}_{4}\right)_{2} \mathrm{CO}_{3}, 98 \%\right)$, dipotassium hydrogenphosphate $\left(\mathrm{K}_{2} \mathrm{HPO}_{4}, 99 \%\right)$, potassium phosphate monobasic $\left(\mathrm{KH}_{2} \mathrm{PO}_{4}\right.$, 99.5\%), ethanol (EtOH, AR) were provided by Sinopharm Chemical Reagent Co., Ltd. Phenylphosphinic acid $\left(\mathrm{C}_{6} \mathrm{H}_{7} \mathrm{O}_{2} \mathrm{P}\right.$, 98\%), polyvinylpyrrolidone (PVP, $M_{\mathrm{wt}}=58000$ ) was supplied by Shanghai Chemical Co. Ltd. Polyvinylpyrrolidone (PVP, $M_{\mathrm{wt}}=$ $40000)$, urea $\left(\left(\mathrm{NH}_{2}\right)_{2} \mathrm{CO}, 98 \%\right)$, cobalt oxide $\left(\mathrm{Co}_{3} \mathrm{O}_{4}\right)$ were purchased from Aladdin Reagent (Shanghai) Co. Ltd. All reagents were used as received without further purification.

\subsection{Synthesis of CoP-X}

\subsubsection{Synthesis of $\mathrm{CoP}-\mathrm{O}$}

A mixture of cobalt acetate tetrahydrate $(0.024 \mathrm{~g}, 0.2 \mathrm{mmol})$ and phenylphosphinic acid (0.014 g, $0.1 \mathrm{mmol})$ was dissolved in $5 \mathrm{~mL}$ of $\mathrm{H}_{2} \mathrm{O}$. Then, the mixture was heated to $140{ }^{\circ} \mathrm{C}$ and kept for $48 \mathrm{~h}$ in a Teflon-lined autoclave. Pink powder (CoP-0) was obtained by washing with water and ethanol, then dried at $70{ }^{\circ} \mathrm{C}$ under vacuum.

\subsubsection{Synthesis of CoP-1}

Cobalt acetate tetrahydrate $(0.024 \mathrm{~g}, 0.2 \mathrm{mmol})$ and phenylphosphinic acid $(0.014 \mathrm{~g}, 0.1 \mathrm{mmol})$ were dissolved in $5 \mathrm{~mL}$ $\mathrm{H}_{2} \mathrm{O}$ separately, then followed by adding the polyvinylpyrrolidone $\left(0.1 \mathrm{~g}, M_{\mathrm{wt}}=40000\right)$ to the above mixture. After ultrasonication for $60 \mathrm{~s}$, the sample were heated to $140{ }^{\circ} \mathrm{C}$ and kept for $48 \mathrm{~h}$ in a Teflon-lined autoclave. After cooling to room temperature, pink powder (CoP-1) was obtained and washed by ethanol and water, then was dried at $70{ }^{\circ} \mathrm{C}$ under vacuum.

\subsubsection{Synthesis of $\mathrm{CoP}-2$}

Cobalt acetate tetrahydrate $(0.024 \mathrm{~g}, 0.2 \mathrm{mmol})$ and phenylphosphinic acid $(0.014 \mathrm{~g}, 0.1 \mathrm{mmol})$ were dissolved in $5 \mathrm{~mL}$ distilled water, respectively. Then these solutions were mixed in a Teflon-lined autoclave, followed by adding polyvinylpyrrolidone $\left(0.1 \mathrm{~g}, M_{\mathrm{wt}}=58000\right)$ without ultrasonication and stirring. The resultant mixed solution was heated to $140{ }^{\circ} \mathrm{C}$ for 48 h. After cooling to room temperature, the pink polycrystals (CoP-2) were obtained by washing with ethanol and water.

\subsubsection{Synthesis of $\mathrm{CoP}-3$}

Phenylphosphonic acid (0.014 g, $0.1 \mathrm{mmol})$, ammonium carbonate $(0.01 \mathrm{~g}, 0.1 \mathrm{mmol})$, urea $(0.015 \mathrm{~g}, 0.25 \mathrm{mmol})$, and cobalt nitrate hexahydrate $(0.029 \mathrm{~g}, 0.1 \mathrm{mmol})$ were dissolved in $3,2,2$, and $3 \mathrm{~mL}$ of distilled water, respectively. After that, the above solutions were mixed in a Teflon-lined autoclave, followed by adding $3 \mathrm{~mL}$ of ethylene glycol to the mixed solu- 
tion. The mixture was heated to $140^{\circ} \mathrm{C}$ for $24 \mathrm{~h}$. After cooling to room temperature, the pink crystals were washed by ethanol and $\mathrm{H}_{2} \mathrm{O}$, then was dried at $70{ }^{\circ} \mathrm{C}$ under vacuum.

\subsection{Characterization}

Field emission scanning electron microscopic (FESEM) images were obtained by a JSM6700-F instrument (Japan). The transmission electron microscopy and high-resolution transmission electron microscopy observations were performed on a transmission electron microscopy (TEM FEI, Tecnai G2 F20) with an accelerating voltage of $200 \mathrm{kV}$. Powder X-ray diffraction (XRD) patterns were recorded on a MiniFlex II X-ray diffractometer with $\mathrm{Cu} K_{\alpha}$ radiation $(\lambda=0.1524 \mathrm{~nm})$ in the range of $3^{\circ}-50^{\circ}$ at a scan rate of $1^{\circ} \mathrm{min}^{-1}$. X-ray photoelectron spectroscopy (XPS) were collected using a Thermo Scientific ESCALAB 250Xi XPS. The binding energy was calibrated using the $\mathrm{C} 1 \mathrm{~s}$ peak energy of $284.6 \mathrm{eV}$. Infrared spectra were recorded using a Bruker Vertex 70 Fourier-transform infrared spectroscopy (FT-IR) spectrometer over the range of 100-4000 $\mathrm{cm}^{-1}$. The surface area (BET) of all samples were measured by $\mathrm{N}_{2}$ adsorption and desorption at $77 \mathrm{~K}$ using a ASAP 2020 sorption system. The samples were degassed off line at $90{ }^{\circ} \mathrm{C}$ for 12 $\mathrm{h}$ under vacuum before the analysis.

\subsection{Electrochemical measurements}

Electrochemical measurements were performed a CHI 760E electrochemical workstation at room temperature $\left(25^{\circ} \mathrm{C}\right)$. Platinum foil and $\mathrm{Ag} / \mathrm{AgCl}(3 \mathrm{M} \mathrm{KCl})$ were used as counter and reference electrode, respectively. The catalysts loaded on a rotating disk electrode (RDE) made of glassy carbon (5 $\mathrm{mm}$ in diameter, $0.196 \mathrm{~cm}^{2}$ ) was used working electrode. The prepared method of the catalyst ink is as follows: As-prepared sample of $5 \mathrm{mg}$ and $8 \mu \mathrm{L}$ of $5 \mathrm{wt} \%$ Nafion solution were dispersed in $500 \mu \mathrm{L}$ of ethanol by ultrasonication for $5 \mathrm{~min}$ to form a homogeneous ink. Then, $6 \mu \mathrm{L}$ of the ink was loaded onto a freshly polished working electrode made of glassy carbon (5 mm in diameter, $0.196 \mathrm{~cm}^{2}$ ), leading to the loading amount of $\sim 0.30 \mathrm{mg} \mathrm{cm}^{-2}$. Before the data was collected, the working electrode was activated using 20 cyclic voltammetry (CV) scans from 0.397 to $1.397 \mathrm{~V}$ vs. NHE at room temperature at a scan rate of $100 \mathrm{mV} \mathrm{s}^{-1}$ with rotating rate of $1600 \mathrm{rpm}$. CV curves were obtained at a scan rate of $20 \mathrm{mV} \mathrm{s}^{-1}$ from 0.397 to $1.397 \mathrm{~V}$ vs. NHE. Linear scan voltammetry (LSV) was collected from 0.397 to $1.397 \mathrm{~V}$ vs. NHE with a scan rate of $5 \mathrm{mV} \mathrm{s} \mathrm{s}^{-1}$ in the neutral media with rotating rate of $1600 \mathrm{rpm}$. The impedance spectrum measurements were collected over a frequency range from $100 \mathrm{kHz}$ to $0.1 \mathrm{~Hz}$ at the voltage of $1.267 \mathrm{~V}$ vs. NHE and the amplitude of the sinusoidal voltage of $5 \mathrm{mV}$, which was used to correct the Tafel plot for $i \mathrm{R}$ drop. Steady-state currents were collected at a variety of applied potentials starting at $1.187 \mathrm{~V}$ vs. NHE and proceeding in $10-20 \mathrm{mV}$ steps to $1.257 \mathrm{~V}$ vs. NHE with rotating rate of $1600 \mathrm{rpm}$, which were used to obtain the Tafel slope. The Tafel plots of these samples were also collected from the steady state current data. According to the Tafel equation of $\eta=\operatorname{blog} j+\mathrm{a}$, which $\eta$ is equal to the over- potential, b represents the Tafel slope, $j$ corresponds to the current density, and $a$ is constant. Overpotential $\eta$ was calculated based on the $\eta=\left(V_{\text {meas }}-\mathrm{iR}\right)-E(\mathrm{pH}=7.0)$ (where $V_{\text {meas }}$ is the measured potential at the $1 \mathrm{~mA} \mathrm{~cm}^{-2}$ ). In order to evaluate the stability, CV was cycled using a scan rate of $100 \mathrm{mV} \mathrm{s}^{-1}$ between a wide potential range from 0.4 to $1.5 \mathrm{~V}$ in $0.1 \mathrm{M}$ phosphate buffer solution. At the end of the repeated CV experiments, LSV curves was recorded at a scan rate of $5 \mathrm{mV} \mathrm{s}^{-1}$ and chronoamperometry data were acquired at the potential of 1.297 V vs. NHE.

\section{Results and discussion}

A structure-directing strategy was adopted to synthesize hierarchical structural metal organic phosphonates as illustrated in Scheme 1 and described in the Experimental section. The morphology and structure of CoP-X were investigated by FESEM and TEM (Fig. 1). In the presence of the low molecular weight of PVP $\left(M_{\mathrm{wt}}=40000\right)$, thorn-shaped CoP-1 was obtained with the average length of $25.5 \pm 0.5 \mu \mathrm{m}$, the width of $0.62 \pm$ $0.03 \mu \mathrm{m}$, and the thickness of $44 \pm 2 \mathrm{~nm}$ (Fig. 1(a)-(c)). When using the high molecular weight of PVP $\left(M_{\mathrm{wt}}=58000\right)$, hierarchical thorn flowers (CoP-2) were observed with an average diameter of $65 \pm 10 \mu \mathrm{m}$ and the thorn thickness of $84 \pm 4 \mathrm{~nm}$ (Fig. 1(d)-(f)). However, when the PVP was replaced by the mixture of ammonium carbonate and ethylene glycol, hierarchical nanosheet flowers (CoP-3) were obtained with an average diameter of $20 \pm 10 \mu \mathrm{m}$ and the nanosheet thickness of 286 $\pm 3 \mathrm{~nm}$ (Fig. 1(g)-(i)). These observations indicate that the shape of as-prepare cobalt phosphonates (CoP-X) depends on the used structure-directing reagent. The crystallographic structure of as-prepared sample was characterized by XRD (Fig. 2(a)). These diffraction peaks can be indexed to cobalt phenylphosphonate $\left(\mathrm{Co}\left(\mathrm{PhPO}_{3}\right)\left(\mathrm{H}_{2} \mathrm{O}\right)\right.$ ] [57], which exhibits a layered structure consisting of inorganic layers of core-sharing

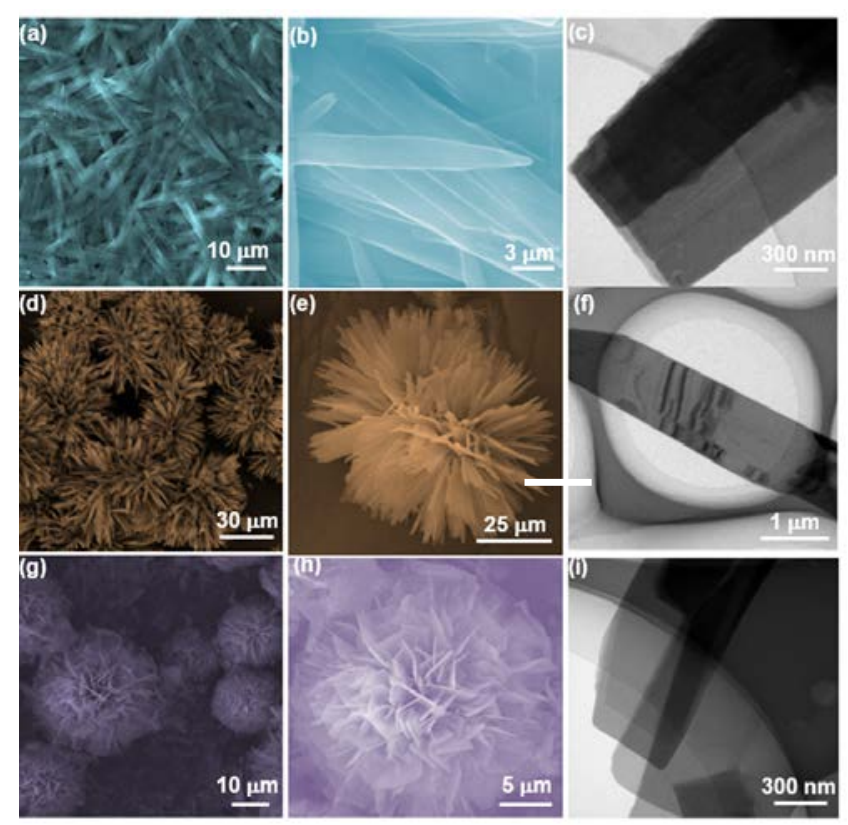

Fig. 1. Representative FESEM and TEM images of CoP-1 (a-c), CoP-2 (d-f), and CoP-3 (g-i). 

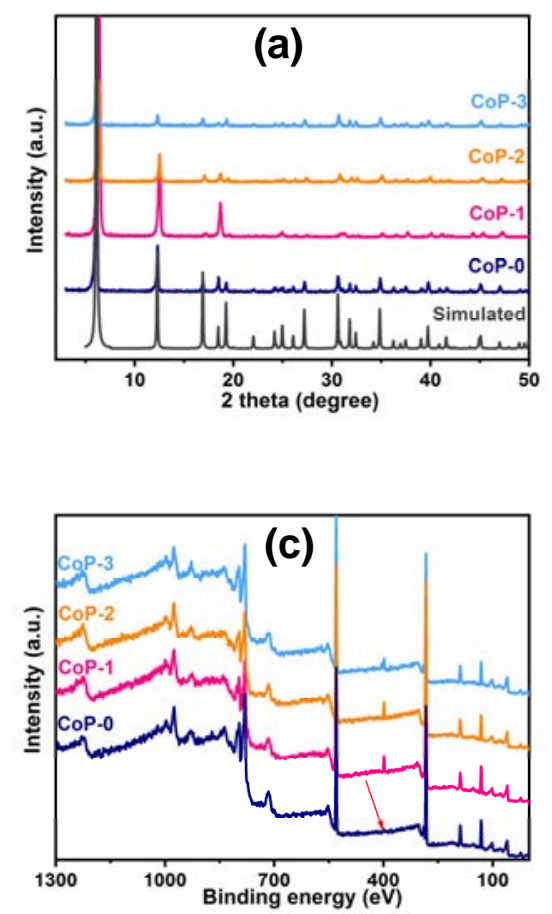
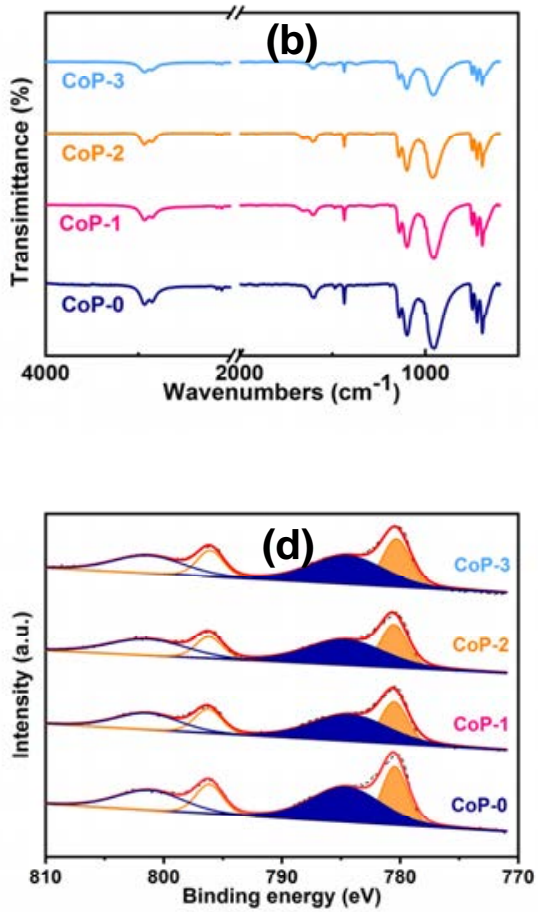

Fig. 2. XRD patterns (a), FT-IR spectra (b), XPS survey spectra (c), and high-resolution Co $2 p$ XPS spectra (d) of CoP-X.

$\mathrm{CoO}_{6}$, and the dangling phenyl ring of phosphonic acid ligand in the interlay space. The chemical composition was further revealed. In the FT-IR spectra of CoP-X (Fig. 2(b)), the obvious peaks at $3466 \mathrm{~cm}^{-1}$ were assigned to the $\mathrm{O}-\mathrm{H}$ stretching vibrations of water molecules, while $1608 \mathrm{~cm}^{-1}$ corresponds to the bending modes of water molecules. The stretching vibrations around $694 \mathrm{~cm}^{-1}$ were ascribed to the $\mathrm{C}-\mathrm{H}$ out-of-plane bends of the monosubstituted phenyl rings. The peaks which from 900 to $1142 \mathrm{~cm}^{-1}$ were attributed to the bending modes of the tetrahedral $\mathrm{CPO}_{3}$ group [58]. The bands below $900 \mathrm{~cm}^{-1}$ could be associated with Co-O stretching vibrations [59]. The valence state and chemical composition of CoP-X were identified by XPS. XPS survey spectra of CoP-X revealed that they possess identical components besides $\mathrm{CoP}-0$ with undetectable $\mathrm{N}$ peak (Fig. 2(c)). This observation was consistent with the fact that CoP-0 was prepared without utilization of nitrogen-containing reagent. The high-resolution Co $2 p$ spectra shows two core-level signals located at 780.5 and $796.2 \mathrm{eV}$ together with two strong satellite peaks at 785.0 and $801.7 \mathrm{eV}$ (Fig. 2(d)), indicating the Co species present an oxidation state of +2 in the as-prepared CoP-X [45]. In the P regions, the $\mathrm{P} 2 p$ spectrum can be deconvoluted into two peaks at 131.4 and $132.3 \mathrm{eV}$ (Fig. S1), corresponding to the binding energies of phosphorus in the C-P and P-O bonds, respectively [53]. These results demonstrate that as-prepared samples have the same chemical composition and crystal structure, despite morphological differences.

To understand the growth process of these morphologies, the possible mechanism was tentatively explored. It was well-known that polyvinylpyrrolidone (PVP) as a class of non-ionic polymer with $\mathrm{C}=\mathrm{O}$ and $\mathrm{C}-\mathrm{N}$ functional group. It has a hydrophilic pyrrolidone and a hydrophobic alkyl chain, and thus was also classified as a non-ionic amphiphile, which was widely used as a stabilizing and structure-directing reagent for the synthesis of metal nanoparticles [60]. Our results showed that PVP can induce the formation of CoP with different shapes, which depends on the molecular weight of PVP. Increasing or decreasing the molecular weight will result in the change in morphology from thorn-like sheet to hierarchical thorn flower. When using low molecular weight of PVP, PVP acts as a surface protecting reagent which prevents the sheets from agglomerating together via the interactions of cobalt centers and the functional groups ( $\mathrm{N}$ and $\mathrm{O}$ ) of PVP to induce the form of uniform thorn-shaped aggregations (CoP-1). Furthermore, no further change in morphology was observed when the reaction time was extended. By contrast, in the absence of PVP, irregular plate-like morphology (CoP-0) were observed (Fig. S2), indicating the ability to disperse material of PVP [61]. Upon further increasing the molecular weight to PVP $\left(M_{\mathrm{wt}}=58000\right)$, thorn-like nanostructures with length of about $30 \mu \mathrm{m}$ were gradually agglomerated into bowie-shaped aggregations and finally were merged into hierarchical flower-like composites (CoP-2). These evolutions could be attributed to increasing the number of hydroxyl groups available as increasing the molecular weight of PVP, which fasten the growth via the hydrogen-bonding interactions at the surface of these thorns. Therefore, the strong interaction of adsorbed PVP molecules could induce material aggregation [62], which lead to various crystal planes of restricted growth. To further investigate the effect of hydroxyl group on the morphology, we introduce ethylene glycol (EG) as structure-directing reagent substituting for PVP to construct CoP-3. Compared with PVP, EG has higher content 
of hydroxyl group and shorter hydrophobic chain. The addition of urea and ammonium carbonate to the solution, while keeping the same reaction condition as that of CoP-2, results in the formation of ultrathin nanosheets. These nanosheet gradually growth into uniform hierarchical flowers (CoP-3). These observations further suggest that the number of hydroxyl group could play a crucial role in tuning the morphology. Meanwhile, this result also suggests that urea was an important contributor to synthesize such ordered nanosheet substructure in the CoP-3. In that case, urea could be decomposed to carbon dioxide and ammonia that gradually increasing basicity, which facilitate the assembling of pristine nanosheets and lead to the growth of hierarchical structure. However, the exact role of how urea regulates the morphology still needs to be further studied.

The water oxidation catalytic properties of CoP-X were performed in $0.1 \mathrm{M}$ phosphate buffer solution $(\mathrm{pH}=7.0)$ with a rotating disk electrode (RDE). For comparison, the catalytic properties of $\mathrm{Co}_{3} \mathrm{O}_{4}$ were also investigated. Before at the start of collected data, $40 \mathrm{CV}$ cycles at a scan rate of $100 \mathrm{mV} \mathrm{s}^{-1}$ from 0.397 to $1.397 \mathrm{~V}$ vs. NHE were performed. After $40 \mathrm{CV}$ sweeps, CV curves of all the samples were collected in $0.1 \mathrm{M}$ phosphate buffer solution in the potential range from 0.397 to $1.397 \mathrm{~V}$ vs. NHE at a scan rate of $20 \mathrm{mV} \mathrm{s}^{-1}$ (Fig. 3(a)). CV curves exhibit a small peak at $1.13 \mathrm{~V}$ vs. NHE followed by onset of water oxidation at $\sim 1.2 \mathrm{~V}$ vs. NHE. The peak at $1.13 \mathrm{~V}$ can be assigned to the Co(II)/Co(III or IV) transitions [10]. On the basis of CV results, the activities increase in the order of CoP- $2>\mathrm{CoP}-1>$
CoP-3 > CoP-0. Further, $i$ R-corrected LSV curves of CoP-X and $\mathrm{Co}_{3} \mathrm{O}_{4}$ were collected from 0.397 to $1.397 \mathrm{~V}$ vs. NHE (Fig. 3(b)). This result demonstrates that CoP-2 exhibits the highest activity with an overpotential of $393 \mathrm{mV}$ required to reach a current density of $1 \mathrm{~mA} \mathrm{~cm}^{-2}$ among these as-prepared samples, though these samples present similar onset potential of $\sim 373 \mathrm{mV}$. It was worth noting that in neutral media water oxidation, the overpotentials were in general evaluated at a current density of $1 \mathrm{~mA} \mathrm{~cm}^{-2}$ [45]. Furthermore, CoP-2 displays a current density of $6.53 \mathrm{~mA} \mathrm{~cm}^{-2}$ at $1.39 \mathrm{~V}$ vs. NHE, which was significantly higher than those of CoP-1 (6.02 mA cm-2), CoP-3 (4.74 mA $\mathrm{cm}^{-2}$ ), and CoP-0 (3.30 mA cm-2 ). Also, the value was higher than that of the classical water oxidation catalyst $\mathrm{Co}_{3} \mathrm{O}_{4}(5.71$ $\mathrm{mA} \mathrm{cm}{ }^{-2}$ ). As shown in Fig. S4, the $\mathrm{Co}_{3} \mathrm{O}_{4}$ shows similar onset potential to CoP-X but high overpotential of $443 \mathrm{mV}$ at a current density of $1 \mathrm{~mA} \mathrm{~cm}-2$. The superior catalytic activity of CoP-2 was also comparable to those of cobalt-based catalysts reported (Table S2). For example, Co-Pi catalyst reaches the current density of $1 \mathrm{~mA} \mathrm{~cm}^{-2}$ required the overpotential of 410 $\mathrm{mV}$ in $0.1 \mathrm{M}$ phosphate buffer solution at $\mathrm{pH}=7$ [45]. The catalytic activity of CoP-X was further confirmed by the Tafel slope (Fig. 3(c)). The Tafel slopes of CoP-1, CoP-2, CoP-3 were determined to be 83,81 , and $92 \mathrm{mV} \mathrm{dec}^{-1}$, respectively, indicating CoP-2 possessed the smallest Tafel slope among these as-prepared samples. The faster electron transfer kinetics of CoP-2 due to the lower Tafel slopes. To verify this speculation, the EIS measurement was conducted. As shown in Fig. 3(d), the Nyquist plot of CoP-2 showed the smallest semicircle among
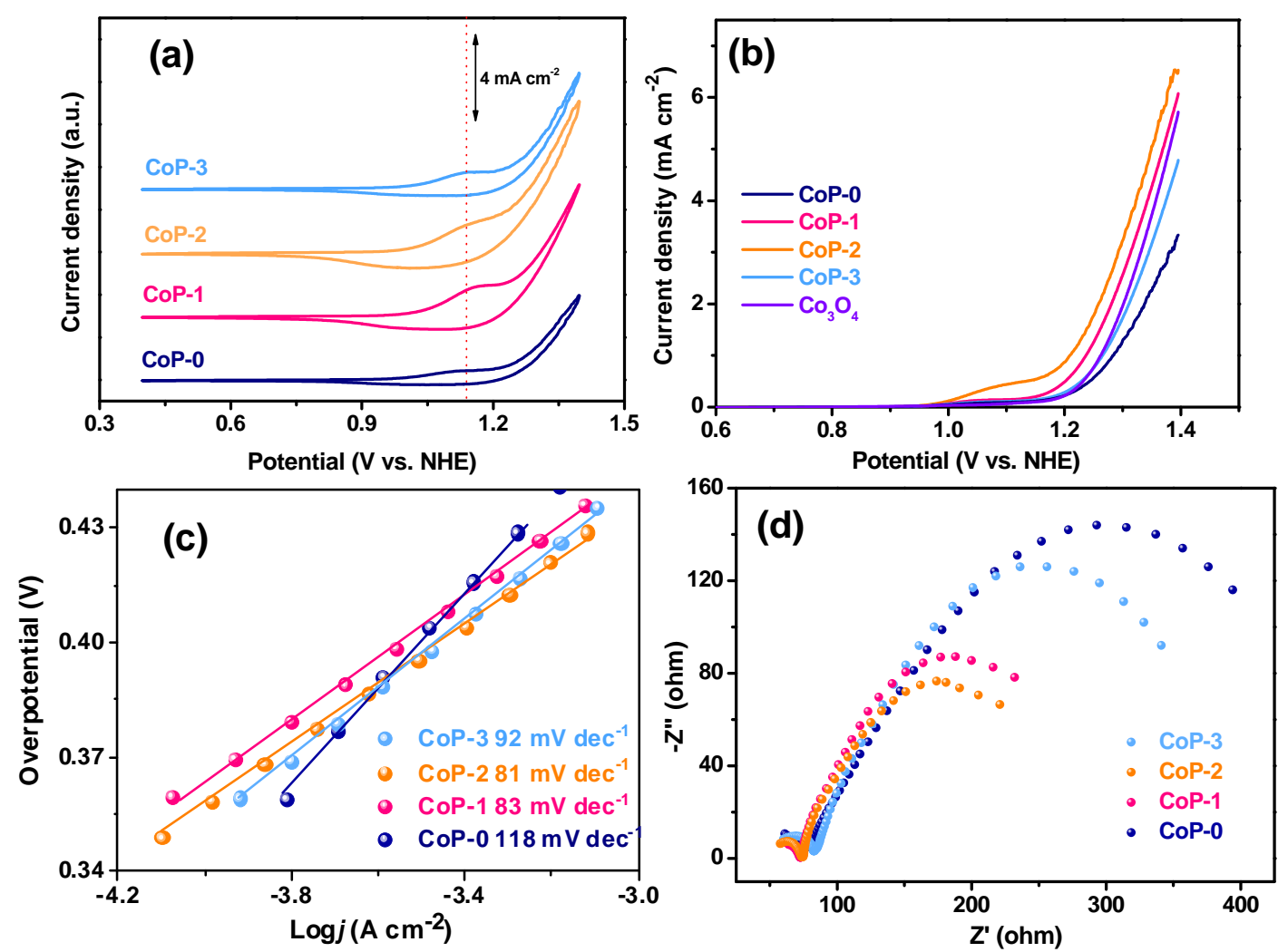

Fig. 3. Water oxidation activity of CoP-X measured at neutral pH. (a) CVs collected at a scan rate of $20 \mathrm{mV} \mathrm{s}{ }^{-1}$; (b) LSV curves obtained at a scan rate of $5 \mathrm{mV} \mathrm{s}^{-1}$; (c) Tafel slopes from steady state current data; (d) Nyquist plots measured at the voltage of $1.267 \mathrm{~V}$ vs. NHE. 
CoP-X samples, demonstrating the faster electron/mass transfer in the CoP-2. However, the collected Tafel slopes were devi-

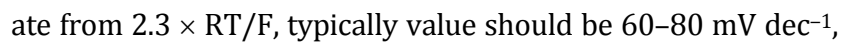
which associated with an one electron-transfer step followed by the rate-determining step [48,53]. Moreover, the mass transport limitation also could cause the deviate from $2.3 \times$ RT/F of Tafel slopes [10]. Additionally, the double layer capacitances $\left(\mathrm{C}_{\mathrm{dl}}\right)$ were measured by different scan rate under a potential range from 0.697 to $0.797 \mathrm{~V}$ vs. NHE, which to estimate the electrochemically active surface area (ECSA). The result showed in Figs. S7 and S8, and Table S1, the CoP-2 enjoyed the highest $C_{\mathrm{dl}}$ of $0.887 \mathrm{mF} \mathrm{cm}-2$, which overtopped CoP-1 $(0.517$ $\mathrm{mF} \mathrm{cm}-2$ ) , CoP-3 (0.446 $\mathrm{mF} \mathrm{cm}^{-2}$ ), and CoP-0 (0.247 $\left.\mathrm{mF} \mathrm{cm}^{-2}\right)$. Furthermore, BET surface area of CoP-X samples (Fig. S9) had the same trend with $C_{\mathrm{dl}}$, that CoP-2 possessed the largest BET surface area of $22.0821 \mathrm{~m}^{2} \mathrm{~g}^{-1}$, followed by CoP-1 $\left(21.7925 \mathrm{~m}^{2}\right.$ $\mathrm{g}^{-1}$ ), CoP-3 (14.7042 $\left.\mathrm{m}^{2} \mathrm{~g}^{-1}\right)$, and CoP-0 (10.2578 $\left.\mathrm{m}^{2} \mathrm{~g}^{-1}\right)$. To explore the intrinsic activity of CoP-X samples, the polarization curves were normalized by the ECSA. As showed in Fig. S10, no significant difference between four samples, and CoP-2 cannot perform as perfect as non-normalized, which indicating the slight difference of intrinsic activity between four sample, and the excellent OER performance of CoP- 2 could be attributed to the largest BET surface area and ECSA [63].

The stability of CoP-X was also investigated. As shown in Fig. S5, the activity of CoP-X displays a small loss after $80 \mathrm{CV}$ cycles in the potential range from 0.397 to $1.397 \mathrm{~V}$ vs. NHE, indicating their high stability during the OER process. The slightly loss of the OER activity could be due to the catalysts falling off from the electrode. The durability of CoP-X was further evaluated by chronoamperometric measurements at $1.297 \mathrm{~V}$ vs. NHE (Fig. S6). The result indicates that the current densities of CoP-X remain nearly unchanged, but CoP-2 presents a higher current density than those of CoP-1 and CoP-3. All of the above results signified that CoP-2 was a stable and efficient OER catalysts. In addition, the XPS, XRD, TEM and FT-IR of CoP-2 after stability test were measured to explore the transform during OER process. In Fig. S11(a) ,the negative shift of binding energy about $1.2 \mathrm{eV}$ for Co $2 p_{3 / 2}$ and $1.7 \mathrm{eV}$ for Co $2 p_{1 / 2}$, the new peaks assigned to $\mathrm{Co}^{3+}$ which emerged at 779.8 and $794.8 \mathrm{eV}$, indicating the rising oxidation state of Co in CoP-2 during OER process [64]. In contrary, the P $2 p$ spectra of CoP-2 after OER measurement (Fig. S11(b)) move to the higher binding energy (from 131.4 to $131.7 \mathrm{eV}$ ), indicating the electronic interaction between Co and P. There were no obvious diffraction peaks observed for CoP-2 after OER test (Fig. S12), suggesting the formation of high valence cobaltic amorphous phase. High-resolution TEM (HRTEM) and the corresponding fast Fourier transformation (FFT) also showed the amorphous nature of CoP-2 after OER test which cannot observed any lattice fringes (Fig. S3). In the FT-IR spectra of CoP-2 after OER test (Fig. S13), no significant change indicating the structure of phosphate groups were maintained.

The high OER performance could be attributed to the phosphonic group which was helpful for the adsorption of water molecules at the surface of electrode. Meanwhile, phosphonate group not only serves as proton acceptors that facilitate the oxidation of Co atoms but also can stabilize the intermediates that promote the water oxidation [50]. In addition, their nanosheet/thorn-like substructure were considered to be an unique advantage for quickly removing the generated bubbles at the surface of electrode [65]. Moreover, the crystalline structure contributes to electron transfer, thus facilitating the OER process. However, the difference of performance was related to their morphology as possible, structure and chemical composition. A combination of XRD, IR, and XPS measurements revealed that they possess nearly identical structure, composition and oxidation state, signifying that the activity could be associated with the morphology. The thinker plates of CoP-0 not only reduce the specific surface area of catalytic sites but also increase the charge transfer resistance as revealed by the impedance spectrum, leading to poor OER performance. In contrast, the thin thorn of CoP-1 was beneficial for the charge transfer at the catalysts/electrolyte interface. In particular, three-dimensional (3D) hierarchical flower-like CoP-2 consisting of thin thorn provides more efficient charge transfer pathways and more exposed accessible surface-active sites. Furthermore, the 3D hierarchical structure can prevent the aggregation of 2D thorn and facilitates the permeation and electrolyte diffusion during OER. However, the thick nanosheet in CoP-3 to some extend affect the charge transfer and lead to inferior performance. The superior OER performance of CoP-2 could be attributed to the synergistic effect of fast charge transfer, increased surface-active sites, and efficient mass transport.

\section{Conclusions}

In summary, we have developed a structure-directing strategy to prepare three different hierarchical structural cobalt phenylphosphonates. The self-assembly mechanism has been studied and it was found that their morphology depended on the number of hydroxyl group of the structure-directing reagent. By introduction of high molecular weight PVP, 3D flower-like aggregations with thin nanothorn was obtained. The 3D hierarchical structure provides some attractive advantages for electrochemical water oxidation, including efficient charge transfer, increased accessible surface-active sites, and a short diffusion distance. As a result, the hierarchical cobalt phosphonate nanothorn flower presents a small overpotential of 393 $\mathrm{mV}$ to catalyze OER with a Tafel slope of $81 \mathrm{mV} \mathrm{dec}^{-1}$ in neutral pH. This work offers a new strategy to develop metal phosphonate/phosphates as high-performance catalysts for OER.

\section{References}

[1] F. Raziq, L. Sun, Y. Wang, X. Zhang, M. Humayun, S. Ali, L. Bai, Y. Qu, H. Yu, L. Jing, Adv. Energy Mater., 2018, 8, 1701580.

[2] S. W. Boettcher, Nat. Catal., 2018, 1, 814-815.

[3] G. M. Whitesides, G. W. Crabtree, Science, 2007, 315, 796-798.

[4] G. Glenk, S. Reichelstein, Nat. Energy, 2019, 4, 216-222.

[5] J.-P. Zou, Y. Chen, S.-S. Liu, Q.-J. Xing, W.-H. Dong, X.-B. Luo, W.-L. Dai, X. Xiao, J.-M. Luo, J. Crittenden, Water Res., 2019, 150, 330-339.

[6] H. Huang, J. Lin, G. Zhu, Y. Weng, X. Wang, X. Fu, J. Long, Angew. 


\section{Graphical Abstract}

Chin. J. Catal., 2020, 41: 1654-1662 doi: S1872-2067(19)63513-8

\section{Hierarchical cobalt phenylphosphonate nanothorn flowers for enhanced electrocatalytic water oxidation at neutral $\mathrm{pH}$}

Mei-Rong Liu, Yang-Peng Lin, Kai Wang, Shumei Chen *, Fei Wang, Tianhua Zhou *

Fuzhou University;

Fujian Institute of Research on the Structure of Matter,

Chinese Academy of Sciences; Sichuan Normal University

The 3D hierarchical cobalt phenylphonate nanothorn flower by a facile hydrothermal synthesis shows an excellent water oxidation performance at neutral $\mathrm{pH}$.

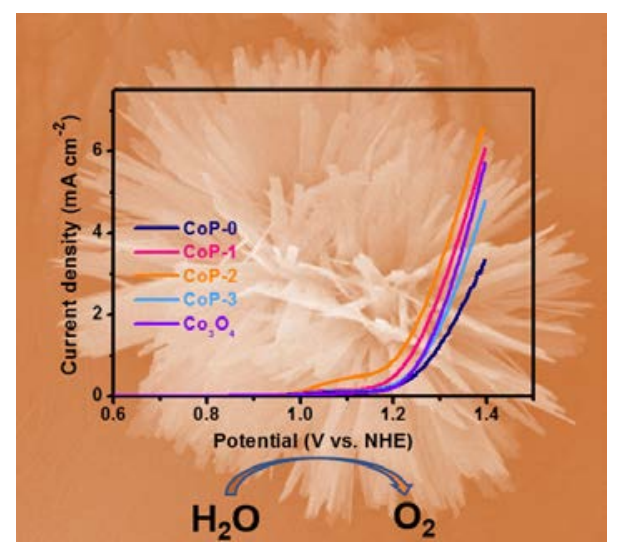

Chem. Int. Ed., 2016, 55, 8314-8318.

[7] G. Cui, X. Yang, Y. Zhang, Y. Fan, P. Chen, H. Cui, Y. Liu, X. Shi, Q. Shang, B. Tang, Angew. Chem. Int. Ed., 2019, 58, 1340-1344.

[8] Y. Guo, P. Wang, J. Qian, Y. Ao, C. Wang, J. Hou, Appl. Catal. B, 2018, 234, 90-99.

[9] W. Liu, J. Shen, X. Yang, Q. Liu, H. Tang, Appl. Surf. Sci., 2018, 456, 369-378.

[10] T. Zhou, D. Wang, S. Chun-Kiat Goh, J. Hong, J. Han, J. Mao, R. Xu, Energy Environ. Sci., 2015, 8, 526-534.

[11] H. N. Nong, T. Reier, H.-S. Oh, M. Gliech, P. Paciok, T. H. T. Vu, D. Teschner, M. Heggen, V. Petkov, R. Schlögl, T. Jones, P. Strasser, Nat. Catal., 2018, 1, 841-851.

[12] M. R. Liu, Q. L. Hong, Q. H. Li, Y. Du, H. X. Zhang, S. Chen, T. Zhou, J. Zhang, Adv. Funct. Mater., 2018, 28, 1801136.

[13] Z. Wang, W. Xu, X. Chen, Y. Peng, Y. Song, C. Lv, H. Liu, J. Sun, D. Yuan, X. Li, X. Guo, D. Yang, L. Zhang, Adv. Funct. Mater., 2019, 29, 1902875.

[14] Z. Chen, Q. Huang, B. Huang, F. Zhang, C. Li, Chin. J. Catal., 2019, 40, 38-42.

[15] F. Li, H. Li, Y. Zhu, J. Du, Y. Wang, L. Sun, Chin. J. Catal., 2017, 38, 1812-1817.

[16] Y. Li, F.-M. Li, X.-Y. Meng, S.-N. Li, J.-H. Zeng, Y. Chen, ACS Catal., 2018, 8, 1913-1920.

[17] P. Cai, J. Huang, J. Chen, Z. Wen, Angew. Chem. Int. Ed., 2017, 56, 4858-4861.

[18] X.-T. Wang, T. Ouyang, L. Wang, J.-H. Zhong, T. Ma, Z.-Q. Liu, Angew. Chem. Int. Ed., 2019, 10.1002/anie.201907595.

[19] B.-Q. Li, C.-X. Zhao, S. Chen, J.-N. Liu, X. Chen, L. Song, Q. Zhang, Adv. Mater., 2019, 31, 1900592.

[20] Q. Qin, H. Jang, P. Li, B. Yuan, X. Liu, J. Cho, Adv. Energy Mater., 2019, 9, 1803312.

[21] J. Chang, Y. Xiao, M. Xiao, J. Ge, C. Liu, W. Xing, ACS Catal., 2015, 5, 6874-6878.

[22] S. She, Y. Zhu, Y. Chen, Q. Lu, W. Zhou, Z. Shao, Adv. Energy Mater., 2019, 9, 1900429.

[23] D. Chen, M. Qiao, Y.-R. Lu, L. Hao, D. Liu, C.-L. Dong, Y. Li, S. Wang, Angew. Chem. Int. Ed., 2018, 57, 8691-8696.
[24] L. Lv, Z. Yang, K. Chen, C. Wang, Y. Xiong, Adv. Energy Mater., 2019 9, 1803358.

[25] D. Zhou, S. Wang, Y. Jia, X. Xiong, H. Yang, S. Liu, J. Tang, J. Zhang, D. Liu, L. Zheng, Y. Kuang, X. Sun, B. Liu, Angew. Chem. Int. Ed., 2019, 58, 736-740.

[26] T. Wang, G. Nam, Y. Jin, X. Wang, P. Ren, M.G. Kim, J. Liang, X. Wen, H. Jang, J. Han, Y. Huang, Q. Li, J. Cho, Adv. Mater., 2018, 30, 1800757.

[27] S. Yin, W. Tu, Y. Sheng, Y. Du, M. Kraft, A. Borgna, R. Xu, Adv. Mater., 2018, 30, 1705106.

[28] J. Zhang, J. Liu, L. Xi, Y. Yu, N. Chen, S. Sun, W. Wang, K. M. Lange, B. Zhang, J. Am. Chem. Soc., 2018, 140, 3876-3879.

[29] J. Li, W. Huang, M. Wang, S. Xi, J. Meng, K. Zhao, J. Jin, W. Xu, Z. Wang, X. Liu, Q. Chen, L. Xu, X. Liao, Y. Jiang, K. A. Owusu, B. Jiang, C. Chen, D. Fan, L. Zhou, L. Mai, ACS Energy Lett., 2019, 4, 285-292.

[30] X. Zhao, B. Pattengale, D. Fan, Z. Zou, Y. Zhao, J. Du, J. Huang, C. Xu, ACS Energy Lett., 2018, 3, 2520-2526.

[31] X.-L. Wang, L.-Z. Dong, M. Qiao, Y.-J. Tang, J. Liu, Y. Li, S.-L. Li, J.-X. Su, Y.-Q. Lan, Angew. Chem. Int. Ed., 2018, 57, 9660-9664.

[32] W. Zhou, D.-D. Huang, Y.-P. Wu, J. Zhao, T. Wu, J. Zhang, D.-S. Li, C. Sun, P. Feng, X. Bu, Angew. Chem. Int. Ed., 2019, 58, 4227-4231.

[33] W. Cheng, X. Zhao, H. Su, F. Tang, W. Che, H. Zhang, Q. Liu, Nat. Energy, 2019, 4, 115-122.

[34] J. Li, W. Huang, M. Wang, S. Xi, J. Meng, K. Zhao, J. Jin, W. Xu, Z. Wang, X. Liu, Q. Chen, L. Xu, X. Liao, Y. Jiang, K.A. Owusu, B. Jiang, C. Chen, D. Fan, L. Zhou, L. Mai, ACS Energy Lett., 2019, 4, 285-292.

[35] F. L. Li, Q. Shao, X. Huang, J. P. Lang, Angew. Chem. Int. Ed., 2018, 57, 1888-1892.

[36] X.-F. Lu, P.-Q. Liao, J.-W. Wang, J.-X. Wu, X.-W. Chen, C.-T. He, J.-P. Zhang, G.-R. Li, X.-M. Chen, J. Am. Chem. Soc., 2016, 138, 8336-8339.

[37] S. Zhao, Y. Wang, J. Dong, C.-T. He, H. Yin, P. An, K. Zhao, X. Zhang, C. Gao, L. Zhang, J. Lv, J. Wang, J. Zhang, A. M. Khattak, N. A. Khan, Z. Wei, J. Zhang, S. Liu, H. Zhao, Z. Tang, Nat. Energy, 2016, 1, 16184.

[38] M. Jiang, J. Chen, Y. Li, Chin. J. Catal., 2018, 39, 1017-1026. 
[39] J. Lin, B. Ma, M. Chen, Y. Ding, Chin. J. Catal., 2018, 39, 463-471.

[40] N. Wang, H. Zheng, W. Zhang, R. Cao, Chin. J. Catal., 2018, 39, 228-244.

[41] X. Wang, Z.-F. Cai, D. Wang, L.-J. Wan, J. Am. Chem. Soc., 2019, 141, 7665-7669.

[42] J. Huang, Y. Sun, Y. Zhang, G. Zou, C. Yan, S. Cong, T. Lei, X. Dai, J. Guo, R. Lu, Y. Li, J. Xiong, Adv. Mater., 2018, 30, 1705045.

[43] P. Feng, X. Cheng, J. Li, X. Luo, ChemistrySelect, 2018, 3, 760-764.

[44] R. Guo, X. Lai, J. Huang, X. Du, Y. Yan, Y. Sun, G. Zou, J. Xiong, ChemElectroChem, 2018, 5, 3822-3834.

[45] M. W. Kanan, D. G. Nocera, Science, 2008, 321, 1072-1075.

[46] M. Risch, V. Khare, I. Zaharieva, L. Gerencser, P. Chernev, H. Dau, J. Am. Chem. Soc., 2009, 131, 6936-6937.

[47] M. W. Kanan, J. Yano, Y. Surendranath, M. Dincă, V. K. Yachandra, D. G. Nocera, J. Am. Chem. Soc., 2010, 132, 13692-13701.

[48] H. Kim, J. Park, I. Park, K. Jin, S. E. Jerng, S. H. Kim, K. T. Nam, K. Kang, Nat Commun, 2015, 6, 8253-8263.

[49] J. Park, H. Kim, K. Jin, B. J. Lee, Y.-S. Park, H. Kim, I. Park, K. D. Yang, H.-Y. Jeong, J. Kim, K. T. Hong, H. W. Jang, K. Kang, K. T. Nam, J. Am. Chem. Soc., 2014, 136, 4201-4211.

[50] Z. Zhao, H. Wu, H. He, X. Xu, Y. Jin, Adv. Funct. Mater., 2014, 24, 4698-4705.

[51] K. Jin, J. Park, J. Lee, K. D. Yang, G. K. Pradhan, U. Sim, D. Jeong, H. L. Jang, S. Park, D. Kim, N.-E. Sung, S. H. Kim, S. Han, K. T. Nam, J. Am. Chem. Soc., 2014, 136, 7435-7443.

[52] C. P. Plaisance, R. A. van Santen, J. Am. Chem. Soc., 2015, 137,
14660-14672.

[53] T. Zhou, Y. Du, D. Wang, S. Yin, W. Tu, Z. Chen, A. Borgna, R. Xu, ACS Catal., 2017, 7, 6000-6007.

[54] R. Zhang, P. A. Russo, A. G. Buzanich, T. Jeon, N. Pinna, Adv. Funct. Mater., 2017, 27, 1703158.

[55] J. Saha, D. Roy Chowdhury, P. Jash, A. Paul, Chem. Eur. J, 2017, 23, 12519-12526.

[56] W.-X. Lu, B. Wang, W.-J. Chen, J.-L. Xie, Z.-Q. Huang, W. Jin, J.-L. Song, ACS Sustainable Chem. Eng., 2019, 7, 3083-3091.

[57] T. O. Salami, X. Fan, P. Y. Zavalij, S. R. J. Oliver, Dalton Trans, 2006, 1574-1578.

[58] T.-H. Zhou, F.-Y. Yi, P.-X. Li, J.-G. Mao, Inorg. Chem., 2010, 49, 905-915.

[59] Z. Liu, R. Ma, M. Osada, K. Takada, T. Sasaki, J. Am. Chem. Soc., 2005, 127, 13869-13874.

[60] K. M. Koczkur, S. Mourdikoudis, L. Polavarapu, S. E. Skrabalak, Dalton Trans., 2015, 44, 17883-17905.

[61] X. W. Lou, L. A. Archer, Adv. Mater., 2008, 20, 1853-1858.

[62] J. S. Chen, J. Liu, S. Z. Qiao, R. Xu, X. W. Lou, Chem. Commun., 2011, 47, 10443-10445.

[63] H. Shi, H. Liang, F. Ming, Z. Wang, Angew. Chem. Int. Ed, 2017, 56, 573-577.

[64] L. Zhan, S. Wang, L.X. Ding, Z. Li, H. Wang, J. Mater. Chem. A, 2015, 3, 19711-19717.

[65] J. Wang, C. F. Tan, T. Zhu, G. W. Ho, Angew. Chem. Int. Ed., 2016, 55, 10326-10330.

\title{
多级纳米喇叭花苯基膦酸钴在中性 $\mathrm{pH}$ 下高效电催化水氧化
}

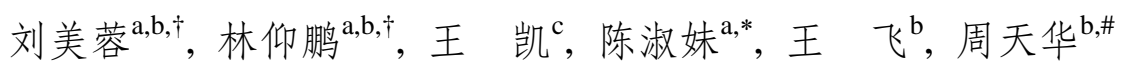 \\ a福州大学化学学院, 福建福州350108 \\ b 中国科学院福建物质结构研究所, 结构化学国家重点实验室, 福建福州350002 \\ ${ }^{\mathrm{c}}$ 四川师范大学化学与材料科学学院, 四川成都610068
}

摘要: 电催化水分解产氢是从根本上解决当前能源及环境等难题的最理想途径. 然而, 由于析氧反应(OER)是一个涉及多 质子耦合电子转移的复杂过程, 其动力学缓慢限制了水分解的效率, 成为光电水分解的速控步骤, 是相关应用发展的一大 瓶颈, 受到学术界与工业界的广泛关注. 如何设计制备出性能高效、稳定性突出、价廉环保的水氧化催化剂, 并揭示构-效 关系及深入理解其催化机制成为该领域的重要课题. $\mathrm{IrO}_{2}$ 和 $\mathrm{RuO}_{2}$ 等贵金属化合物被公认为当前最好的电催化析氧催化剂, 但高成本及稀缺性严重限制了它们大规模应用. 为此, 开发高效低成本廉价过渡金属OER催化剂成为能源催化学科的研 究热点与重点.

在已报道的过渡金属催化剂中, 原位电沉积制备的磷酸钴 $(\mathrm{Co}-\mathrm{Pi})$ 被认为是迄今为止最有效的OER催化剂之一. 尽管 Co-Pi展现出诱人的性能, 但无序的非晶态结构限制了对其结构进行精确描述, 至今它的详细结构尚没有定论. 由于其在结 构方面的局限性, 影响了进一步揭示水氧化催化剂构-效关系及深入理解水氧化机理. 作为引入磷酸基构筑的晶态金属有 机骨架材料, 其柔性的多阴离子官能团可能带来更多可调控的结构因素, 其丰富的可调控结构因素有助于从原子-分子水 平上揭示水氧化催化剂构-效关系及加深理解其反应机理, 使其有望成为一种最有希望的新型水氧化催化剂. 近来, 在研究 水氧化功能的金属有机膦酸盐材料时, 我们发现八面体钴的桥联方式以及钴与钴、钴与氧键长细微差别, 却展现出不同水 氧化活性. 然而, 迄今为止, 关于水氧化功能的金属有机骨架材料特别膦酸盐骨架材料研究仍未见系统研究, 并且目前报 道的水氧化功能金属有机膦酸盐材料, 主要是从晶体结构角度揭示其构-效关系以及理解其反应机理, 此外, 尚未见相关工 作探讨形貌对OER催化性能影响. 系统研究形貌自组装机制并进一步揭示它们对材料水氧化性能的影响无疑至关重要.

因此本文发展一种结构导向策略, 通过水热法构建不同形貌的苯膦酸钴(CoP-X) OER催化剂, 系统考察了它们的自组 装机理及催化性能.研究发现, 在不使用结构导向试剂时, 合成的CoP-0为不规则的片状结构, 而当引入分子量为 40000 的 PVP结构导向试剂, 能获得针状形貌的CoP-1. 当分子量增加到 58000, 能进一步组装得到层状纳米喇叭花状的CoP-2. 这可 能是因为低分子量的PVP的官能团(N和O)与金属中心相互作用阻止纳米片的团聚. 当PVP分子量进一步增加, 导致羟基数 量随着增加, 材料表面的氢键相互作用从而加速材料生长. 为了进一步研究羟基对形貌的影响, 用乙二醇代替PVP并加入 
尿素和碳酸铵, 则合成出均匀层状花形貌的CoP-3. 我们推测可能是羟基的数量在调整形貌方面起着决定作用, 而且尿素 可以增加溶液碱度, 促进多级结构的生长. 电催化水氧化结果表明, 在 $0.1 \mathrm{M} \mathrm{PBs}$ 溶液中 $(\mathrm{pH}=7.0)$, 纳米喇叭花状的 $\mathrm{CoP}-2$ 的OER活性最好, 在 $1 \mathrm{~mA} \mathrm{~cm}$ 处的过电势仅为 $393 \mathrm{mV}$, Tafel斜率为 $81 \mathrm{mV} \mathrm{dec}^{-1}$. 这为了发展新型金属有机膦酸盐水氧化 催化剂提供了一个新思路.

关键词: 金属有机膦酸盐; 形貌; 电催化; 中性pH值; 氧析出反应; 磷酸缓冲溶液

收稿日期: 2020-02-25. 接受日期: 2020-03-29. 出版日期: 2020-10-05.

*通讯联系人. 电话: (0591)63179450; 电子信箱: csm@fzu.edu.cn

\#通讯联系人. 电子信箱: thzhou@fjirsm.ac.cn

†共同第一作者.

基金来源：国家自然科学基金(51772291, 21871050).

本文的电子版全文由Elsevier出版社在ScienceDirect上出版(http://www.sciencedirect.com/science/journal/18722067). 